Research article

\title{
Comparison of an immortalized human corneal epithelial cell line with Vero cells in the isolation of Herpes simplex virus-I for the laboratory diagnosis of Herpes simplex keratitis Sreedharan Athmanathan*1, Sesha B Reddy ${ }^{1}$, Rishita Nutheti ${ }^{2}$ and Gullapalli N Rao ${ }^{3}$
}

Address: ${ }^{1}$ Jhaveri Microbiology Center, Prof. Brien Holden Eye Research Center, Hyderabad Eye Research Foundation, L. V. Prasad Eye Institute, L. V. Prasad Marg, Banjara Hills, Hyderabad, India, ${ }^{2}$ International Centre for Advancement of Rural Eye care, L. V. Prasad Eye Institute, L. V. Prasad Marg, Banjara Hills, Hyderabad, India and ${ }^{3}$ Cornea services, L. V. Prasad Eye Institute, L. V. Prasad Marg, Banjara Hills, Hyderabad, India

E-mail: Sreedharan Athmanathan* - sreedhar@lvpeye.stph.net; Sesha B Reddy - sreedhar@lvpeye.stph.net; Rishita Nutheti - rishita@lvpeye.stph.net; Gullapalli N Rao - gnrao@lvpeye.stph.net

${ }^{*}$ Corresponding author

Published: 30 April 2002

BMC Ophthalmology 2002, 2:3

This article is available from: http://www.biomedcentral.com/I47I-24I5/2/3

(C) 2002 Athmanathan et al; licensee BioMed Central Ltd. Verbatim copying and redistribution of this article are permitted in any medium for any purpose, provided this notice is preserved along with the article's original URL.
Received: 19 November 2001

Accepted: 30 April 2002

\begin{abstract}
Background: Herpes simplex keratitis (HSK) is a sight threatening ocular infection often requiring a specific and prompt laboratory diagnosis. Isolation of Herpes simplex virus (HSV-I) in culture provides the most reliable and specific method and is considered as the "Gold Standard" in the laboratory diagnosis of HSK in spite of its low sensitivity. Using "cell lines of corneal origin" for virus isolation may be beneficial under such circumstances, since these cells have been shown to be excellent substrates for the growth of HSV-I isolated from the cornea. We report a comparative study of a novel human corneal epithelial cell line (HCE) and the Vero cell line in the isolation of HSV-I from corneal scrapings employing a shell vial assay.
\end{abstract}

Methods: Corneal scrapings were obtained from 17 patients with a clinical diagnosis of HSK. All the cases were confirmed by virological investigations (PCR and viral antigen detection positive, $n$ $=15$, PCR positive, $n=1$, Viral antigen positive, $n=1$ ). Scrapings obtained from 10 patients with infectious keratitis of non-viral origin were included as controls. All the scrapings were simultaneously inoculated into shell vials of HCE and Vero cells. Cultures were terminated at $24 \mathrm{~h}$ post-infection. Isolation of HSV-I was confirmed using an indirect immunofluorescence/ immunoperoxidase assay.

Results: Virus could be isolated using both or either of the cell lines in 10/17 (58.82\%) patients with HSK. HSV-I was isolated from $10 / 17$ (58.82\%) and 4/I7(23.52\%) specimens in HCE and Vero cells, respectively $(P=0.036)$. None of the controls yielded HSV-I. While all the $10(100 \%)$ strains were isolated in HCE, Vero yielded only $4 / 10(40 \%)$ strains in the shell vial culture $(P=0.014)$.

Conclusions: HCE showed a statistically significant difference in the virus isolation rate with respect to Vero cells. HCE may be an excellent alternative cell line for the isolation of HSV-I, especially from corneal scrapings, for the laboratory diagnosis of HSK. 


\section{Introduction}

Herpes simplex keratitis (HSK), a leading cause of corneal blindness, is a sight threatening ocular infection often requiring a specific and prompt laboratory diagnosis [1]. A variety of techniques have been employed for the rapid diagnosis of HSK [2-5]. Isolation of Herpes simplex virus1(HSV-1) in culture provides the most reliable and specific method and is considered as the "Gold Standard" in the laboratory diagnosis of HSK. However, the sensitivity of this technique has been found to be low [6]. The reasons for this low sensitivity, especially for the isolation of HSV1 from corneal scrapings, may be attributed to the sensitivity of the cell line used and the small volume of the specimen available. A number of cell lines are currently being used for the rapid isolation of HSV-1 in cell culture including primary rabbit kidney cells, human fetal foreskin fibroblasts, human embryonic lung fibroblasts and Vero [7].

A recent study has reported that isolates derived from herpetic keratitis grow better in corneal epithelial cells and rabbit corneal epithelial cells may be more suitable for isolating HSV from the cornea [8]. Therefore, we performed a prospective study comparing the efficacy of a recently described novel immortalized human corneal epithelial cell line [9] and Vero cells in the isolation of HSV-1 from corneal scrapings obtained from patients with HSK.

\section{Methods}

\section{Specimens}

Corneal scrapings were obtained following informed consent, from 17 patients with a clinical diagnosis of HSK. All the cases were confirmed by virological investigations (PCR and Viral antigen detection positive, $\mathrm{n}=15$, PCR positive, $\mathrm{n}=1$, Viral antigen positive, $\mathrm{n}=1$ ). Scrapings obtained from 10 patients with infectious keratitis of non-viral origin (Bacterial keratitis: $\mathrm{n}=4$, Mycotic keratitis: $\mathrm{n}=$ 3, Acanthamoeba keratitis: $\mathrm{n}=1$, Keratitis due to Nocardia $s p p: \mathrm{n}=1$, and Mycobacterium $s p p: \mathrm{n}=1$ ), were included as controls. Specimens were transferred to a vial containing $1 \mathrm{ml}$ of viral transport medium (VTM), transported to the virology laboratory immediately and frozen at $-70^{\circ} \mathrm{C}$ until they were processed for virus cultures.

\section{Cell lines}

HSV-1 was isolated employing a shell vial assay. HCE (fig. 1) (Kind gift from Dr. Araki-Sasaki, K., Osaka University Medical School, Osaka, Japan) and Vero (National facility for animal tissue and cell cultures, Pune, Maharashtra, India) shell vials were prepared as per standard protocols. The HCE cell line has been established by immortalizing primary cultured human corneal epithelial cells (obtained from a donor cornea) with a recombinant SV40-adenovirus vector and cloned three times to obtain a continuously

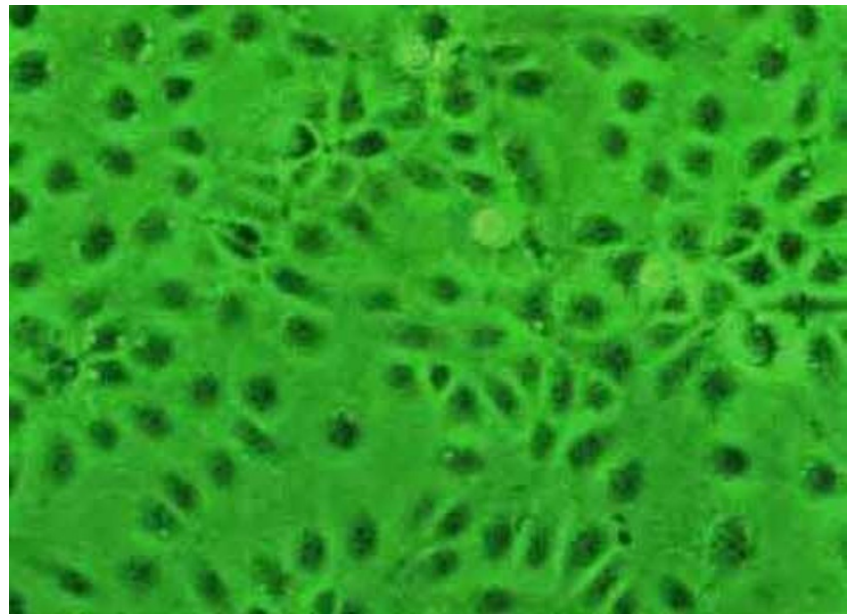

Figure I

Monolayer of HCE. Shell vial culture, Phase contrast microscopy, $\times 100$.

growing cell line. This cell line has been shown to have properties similar to normal human corneal epithelial cells [9]. HCE cells were grown using the supplemented hormonal epithelial medium (SHEM) consisting of equal volumes of MEM and Ham's nutrient mixture F-12 supplemented with 5\% (vol./vol.) heat inactivated fetal bovine serum (FBS), $5 \mu \mathrm{g} / \mathrm{ml}$ insulin, $0.1 \mu \mathrm{g} / \mathrm{ml}$ Cholera toxin, $10 \mathrm{ng} / \mathrm{ml}$ human epidermal growth factor, $0.5 \%$ dimethyl sulfoxide and $40 \mu \mathrm{g} / \mathrm{ml}$ gentamicin. All the reagents were obtained from Sigma, St. Louis MO. Vero cells were grown using MEM supplemented with 5\% FBS.

\section{Suitability and susceptibility of HCE for the isolation of HSV-I by a shell vial assay and tube culture}

The HCE was assessed for its suceptibility to HSV-1 and its suitability for the isolation of HSV-1 by a shell vial assay and conventional tube culture, since such aspects of this cell line have not been described earlier. Briefly, a strain of HSV-1 (HSV-1, McIntyre, ATCC, V-539, Vero culture supernatant, $100 \mathrm{PFU}$ in $500 \mu \mathrm{l}$ ) was inoculated into a shell vial and tube culture of HCE. The tube cultures were observed for the evidence of cytopathic effect (CPE) everyday for 4 days. Shell vial cultures were examined the next day $(12-16 \mathrm{~h})$ following the day of specimen inoculation. Shell vial and tube cultures were terminated and the cells harvested at $24 \mathrm{~h}$ and $96 \mathrm{~h}$ post-infection, respectively. HSV-1 isolation was confirmed using an indirect immunofluorescence/ immunoperoxidase assay.

\section{Shell vial cultures using clinical specimens}

For the shell vial cultures, specimens collected in VTM were thawed, vortexed vigorously for 30 seconds and an equal volume $(0.5 \mathrm{ml} / \mathrm{vial})$ of the sample was inoculated into a vial of HCE and Vero cells. The vials were then cen- 
trifuged at $700 \times \mathrm{g}$ for 1 hour at room temperature and were incubated at $36^{\circ} \mathrm{C}$ for 1 hour for adsorption. The supernatant was discarded and $1 \mathrm{ml}$ of maintenance medium (SHEM Supplemented with 1\% FBS for HCE and MEM with $1 \%$ FBS for Vero cells) was added. The vials were incubated for 24 hours at $36^{\circ} \mathrm{C}$. Based on our suceptibility assay results, routine examination of the cell cultures were done the next day $(12-16 \mathrm{~h})$ following the day of specimen inoculation, for any evidence of CPE. Cultures were terminated at $24 \mathrm{~h}$ post-infection. Isolation of HSV-1 was confirmed employing an indirect immunofluorescence assay using a polyclonal antibody to HSV-1 (Dako, Capinteria, LA). Two types of positivity were observed: qualitative (presence of cells with specific fluorescence) and quantitative (number of infectious foci (IF) present in each shell vial), as described previously [10].

Statistical analysis was performed on results using a computer assisted statistical program (Epi Info, Version 6.04 b, CDC, USA). Chi square test for proportions (with Yates correction when required) was used. All $P$ value were considered significant if less than 0.05 .

\section{Results}

Susceptibility of HCE to HSV-I and its suitability for the isolation of HSV-I

The HCE was found to be suceptible to HSV-1 as determined by both the shell vial and tube cultures. Cytopathic effect (CPE) (fig. 2) was seen in the tube cultures at $48 \mathrm{~h}$ ( $>50 \%$ of the cells were refractile, showed rounding and ballooning). Shell vial culture showed such changes in few cells $(<10 \%)$ at $12-16 \mathrm{~h}$ post-infection. Nevertheless, both the cultures showed the presence of infected cells as determined by the Immunofluorescence/ Immunoperoxidase assay (figs. 3,4) suggesting that the HCE was suitable for use in the shell vial assay and tube cultures, for the isolation of HSV-1.

\section{Shell vial cultures using clinical specimens}

Virus could be isolated using both or either of the cell lines from 10/17 (58.82\%) specimens collected from patients with HSK (figs. 5,6,7,8). None of the controls yielded HSV-1. HSV-1 was isolated from 10/ 17 (58.82\%) and $4 / 17(23.52 \%)$ specimens obtained from patients with HSK in HCE and Vero cells, respectively $(P=0.036)$ (Table 1). The sensitivity, specificity, PPV and NPV are shown in Table 1 . While all the $10(100 \%)$ strains were isolated in HCE, Vero yielded only 4/10 (40\%) strains in the shell vial culture $(P=0.014)$ (Table 2$)$. The HCE showed a statistically significant difference in the virus isolation rate with respect to Vero cells. An unexpected finding in this study was that two of the specimens inoculated into the HCE showed CPE during routine examination of cultures at $12 \mathrm{~h}$ and $16 \mathrm{~h}$, respectively (fig. 5). Such an observation was not seen in Vero cells.

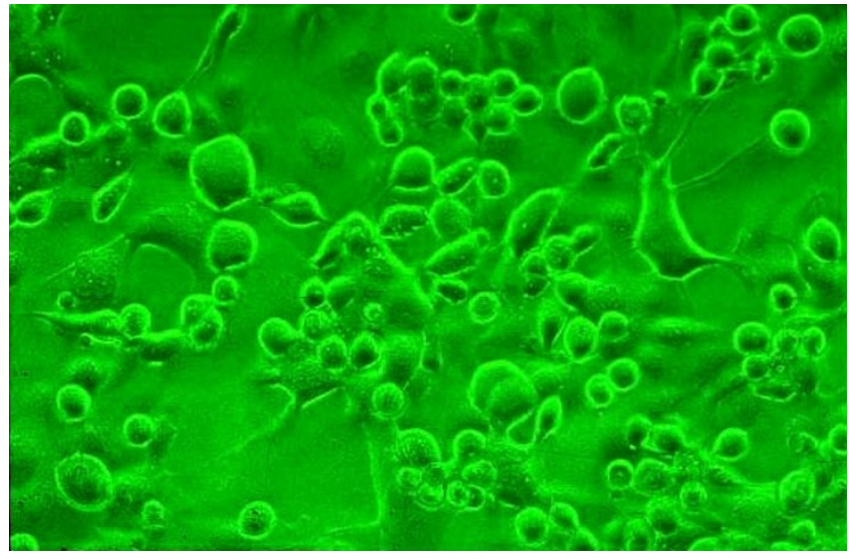

\section{Figure 2}

HCE showing CPE. Conventional tube culture, Phase contrast microscopy, $\times 100$.

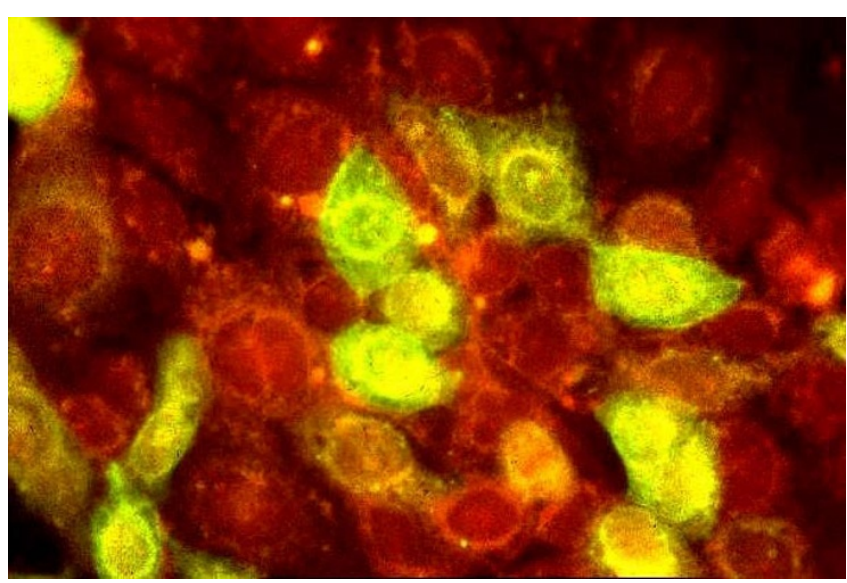

Figure 3

HSV-I (Mclntyre) infected HCE. Note the virus-infected cells showing apple green fluorescence. Uninfected cells are stained red due to the counterstain. Indirect immunofluorescence assay, $\times 400$.

Considering the quantitative analysis (Table 3), HCE performed better than Vero cells, based on the number of IF present in the monolayers. HSV-1 was isolated in both the cell lines (3/3), when the viral load was high (> 20 IF). In contrast, HCE yielded more number of isolations $(7 / 7)$ than Vero $(1 / 7)$ when the viral load was relatively low (< $20 \mathrm{IF})(P=0.0069$, Table 3$)$. It is interesting to note that the virus could not be isolated in vero cells when the viral load was very low ( $<10 \mathrm{IF}$ ) while there were 4 isolations in HCE (Table 3).

\section{Discussion}

This study was performed to assess the relative sensitivity of a recently described HCE and the Vero cells based on an 
Table I: Qualitative results of HSV-I isolation in HCE and Vero cells $(n=27$, Cases: 17 [true positives], Controls: 10 [true negatives])

\begin{tabular}{lccccc}
\hline Cell line & True + ves & True - ves & Sensitivity(\%) & Specificity(\%) & PPV(\%) \\
\hline HCE + ve & 10 & 0 & 58.82 & 100 & 100 \\
HCE - ve & 7 & 10 & 0 & 100 & 100 \\
Vero + ve & 4 & 10 & 23.52 & 43.47 \\
Vero - ve & 13 & 10.82 & \\
\hline
\end{tabular}

Table 2: Details of HSV-I isolation in HCE and Vero cells $(n=10)$

\begin{tabular}{lc}
\hline Cell line & No. of strains isolated \\
\hline & \\
HSV-I isolated in HCE and Vero & 4 \\
HSV-I isolated in HCE only & 6 \\
HSV-I isolated in Vero only & 0 \\
Total no. of strains isolated & 10 \\
\hline
\end{tabular}

Table 3: Quantitative results of HSV-I isolation in HCE and Vero based on number of IF present in each shell vial.

\begin{tabular}{lll}
\hline No. of IF & \multicolumn{2}{l}{ No. (\%) of samples in cell line } \\
\hline & HCE & Vero \\
\hline $1-10$ & & \\
$11-20$ & $4(100)$ & $0(0)$ \\
$>20$ & $3(100)$ & $1(33.3)$ \\
Total & $3(100)$ & $3(100)$ \\
& $10(100)$ & $4(40)$ \\
\hline
\end{tabular}

earlier observation that corneal epithelial cells may be more suitable for the isolation of HSV from the cornea [8].

Vero cells were chosen for comparison since our earlier observations over a two-year period (unpublished data) suggested that this cell line performs better than HEp2/ BHK-21/ HeLa or A549 in the isolation of HSV-1 from patients with HSK. We employed the shell vial assay since this technique has been shown to be a rapid and sensitive method for the isolation of HSV [11] and adenovirus [12] from ocular specimens when compared to the conventional tube cultures.

Assays done to determine the performance characteristics of HCE show that this cell line is susceptible to HSV-1 and

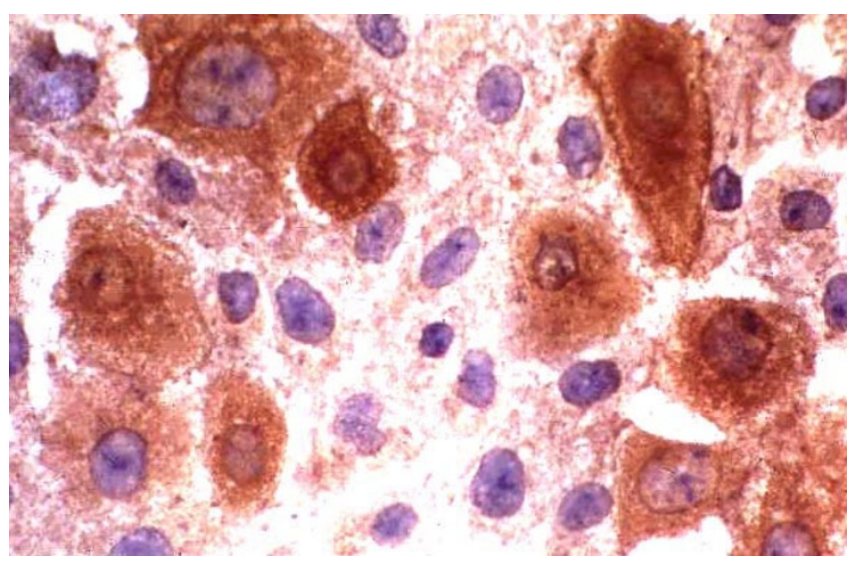

\section{Figure 4}

HSV-I (Mclntyre) infected HCE. Virus infected cells are stained brown. Uninfected cells are stained blue due to the counterstain. Indirect immunoperoxidase assay, $\times 500$.

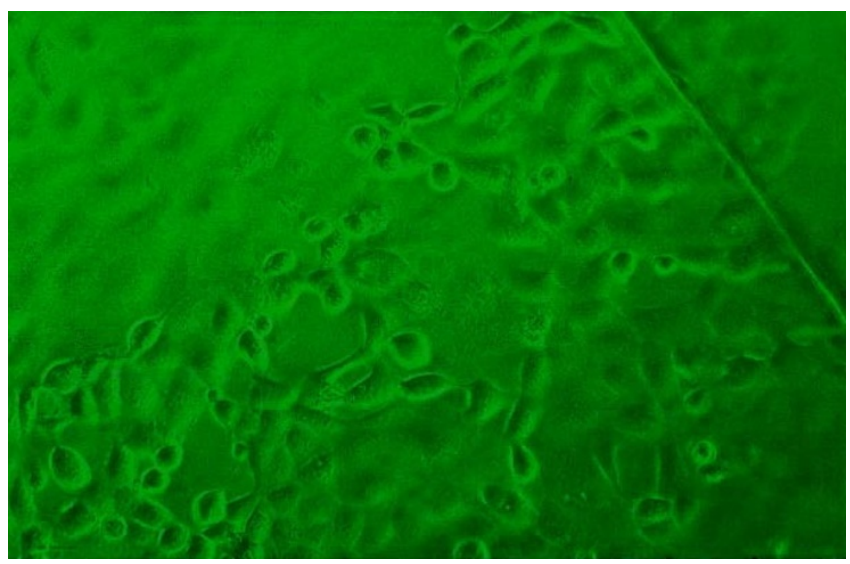

\section{Figure 5}

HCE inoculated with a clinical specimen showing CPE at $12 \mathrm{~h}$ in the shell vial assay. Note the presence of some rounded and refractile cells on the cover slip. The edge of the cover slip is also seen. Phase contrast microscopy, $X$ 40. 


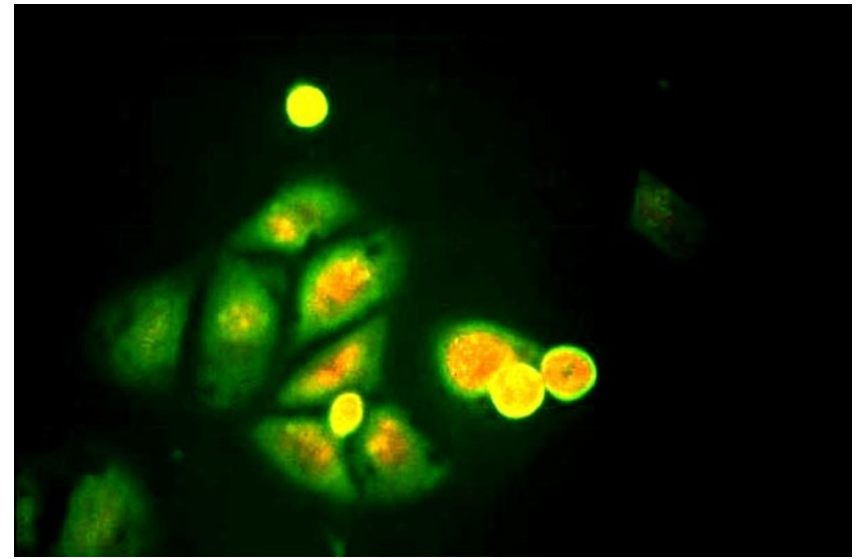

Figure 6

HCE inoculated with a low viral load clinical specimen positive for HSV-I. Note the presence of very few infected cells showing apple green fluorescence. Indirect immunofluorescence assay, $\times 250$.

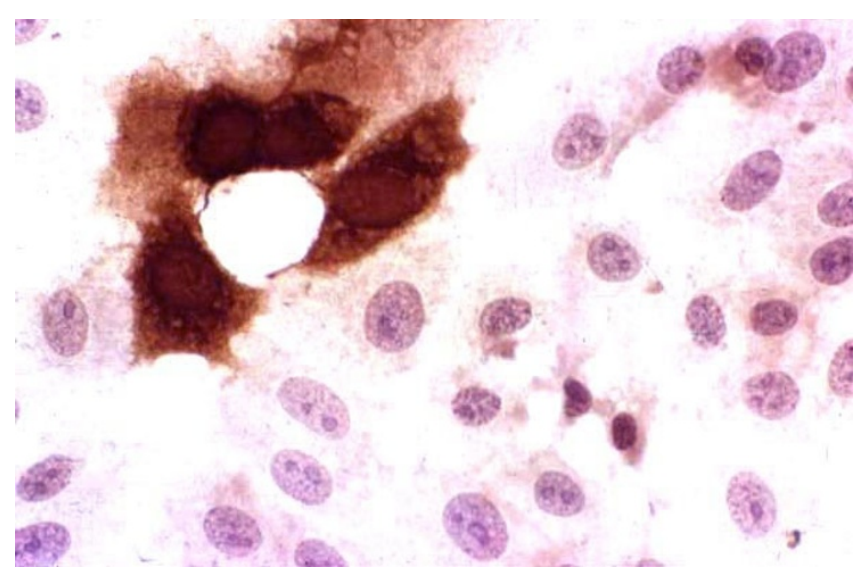

Figure 7

HCE inoculated with a low viral load clinical specimen positive for HSV-I. Note the presence of very few infected cells, which are stained brown. Indirect immunoperoxidase assay, $\times 500$.

suitable for the isolation of the virus from corneal scrapings in a shell vial assay.

Our results show that the HCE is superior to Vero in the isolation of HSV-1, both in the qualitative and quantitative analysis. Considering the qualitative analysis, it is interesting to note that HCE yielded the maximum number of isolations. There were no cases where HSV-1 was isolated only in Vero cells (Table 2), which suggests the increased sensitivity of the HCE. While there was a statistically significant difference in the sensitivity of these two cell lines for virus isolation, the specificity and PPV were very good (100\%, Table 1$)$. However, the low NPV

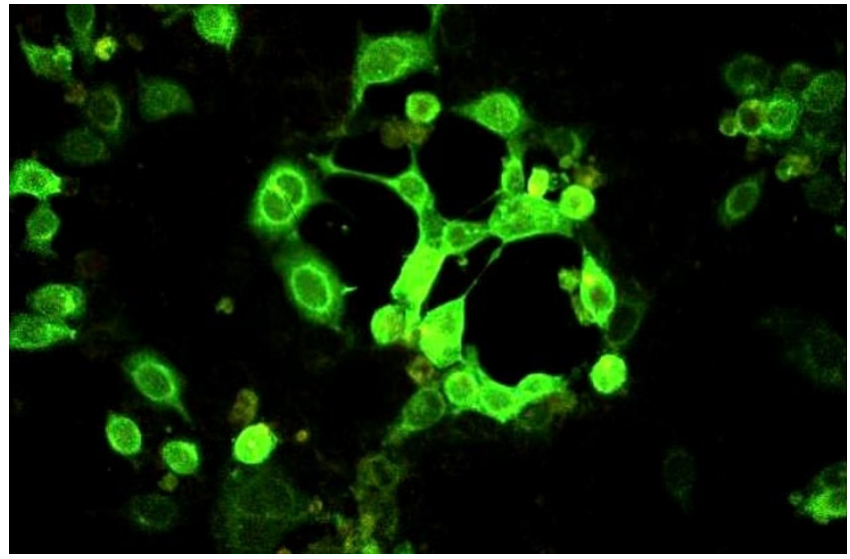

Figure 8

HCE inoculated with a high viral load clinical specimen positive for HSV-I. Note the presence of many infected cells showing apple green fluorescence. Indirect immunofluorescence assay, $\times 125$.

of both the cell lines (Table 1) suggests that there is a need for better cell lines, especially for the isolation of virus from corneal scrapings. Further, it is worthwhile to note that CPE can be observed in HCE earlier than in conventional tube cultures, in some specimens, as seen in this study. Such specimens can be processed for imunofluorescence/ immunoperoxidase assay immediately leading to a "reduced turn around time" of reporting the results.

Analysis of the quantitative results showed that HCE had the greatest sensitivity irrespective of the viral load, while vero had similar sensitivity to that of HCE only when the load was high (Table 3 ). HCE proved to be very beneficial, especially when the viral load was low (< 10 IF) (Table 3 ).

It is obvious from the results that HSV-1 can be more often isolated in HCE than Vero. This has been shown both by qualitative and quantitative analysis.

In general, the isolation rates of HSV-1 in cultures from corneal specimens have been low [6], irrespective of the cell line used. Our earlier report showed a similar trend wherein we could isolate HSV-1 in Vero cells only in 5/15 (33.3\%) specimens obtained from patients with HSK [13]. This study demonstrates that using HCE can further increase the virus isolation rate.

The rate of isolation of HSV-1 from corneal scrapings has increased from $33.3 \%$ to $58.82 \%$ in our laboratory employing the HCE, as seen in this study. We have used an inoculum size of $0.5 \mathrm{ml}$ of the specimen in our study. It has earlier been shown that increasing the inoculum size of the specimen can further increase the sensitivity of the 
shell vial assay [14]. Such studies are being done at our laboratory.

We have shown the superiority of HCE over Vero cells in the isolation of HSV-1 from corneal scrapings for the laboratory diagnosis of HSK, in this preliminary study. However, the results should be interpreted with caution, since the sample size is small. Further studies are warranted using an adequate sample size. Such a study is being pursued in our laboratory.

To the best of our knowledge based on a "MEDLINE" search, this is the first report of the HCE being used for the isolation of HSV-1 in a shell vial assay for the laboratory diagnosis of HSK. We believe that the inclusion of this cell line, when available, in the routine culture protocols of ocular virology laboratories would result in a significant increase in the diagnostic yield.

\section{Commercial interests}

None declared

\section{Acknowledgements}

This study was supported by the Hyderabad Eye Research Foundation, Hyderabad, India.

We thank all the patients for participation in this study, Dr. Prashant Garg, Dr. Nibaran Gangopadhyay for the clinical evaluation and collection of corneal scrapings from the patients with HSK and Mr. S. B. N Chary for excellent photography.

\section{References}

I. Yamamoto SY, Shimomura Y, Kinoshita S, Nishida K, yamamoto R, Tano $Y$ : Detection of herpes simplex virus DNA in human tear film by polymerase chain reaction. Am J Ophthalmol 1994, I | 7:160-163

2. Espy MJ, Uhl JR, Mitchell PS, Thorvilson JN, Wold AD, Smith TF: Diagnosis of herpes simplex virus infection in the clinical laboratory by Light Cycler PCR. I Clin Microbiol 2000, 38:795-799

3. Kowalski RP, Gordon Y]: Evaluation of immunologic tests for the detection of ocular herpes simplex virus. Ophthalmology 1989, 96:1583-1586

4. Thiel MA, Bossart W, Bernauer W: Improved impression cytology techniques for the immunopathological diagnosis of superficial viral infections. $\mathrm{Br}$ / Ophthalmol 1997, 81 :984-988

5. Asbell PA, Torres MA, Kamenar T, Botone EJ: Rapid diagnosis of ocular herpes simplex infections. Br J Ophthalmol I 995, 79:473475

6. Kaye SB, Baker K, Bonshek K, Maseruka H, Grinfeld E, Tullo A, Easty $\mathrm{DL}, \mathrm{Hart} \mathrm{CA}$ : Human herpes viruses in the cornea. $\mathrm{Br}$ J Ophthal$\mathrm{mol}$ 2000, 84:563-57।

7. Buthod LM, Schindler NL, Rogers HW: Determination of cell line suitability for rapid isolation of herpes simplex virus. I Virol Methods 1987, 18:37-46

8. Mori Y, Shimomura Y, Inoue Y, Kinoshita S: Susceptibility of cultured rabbit corneal epithelial cells to various herpes simplex virus isolates. Jpn J Ophthalmol 1996, 40:367-370

9. Araki-Sasaki K, Ohashi KY, Sasabe T, Hayashi H, Watanabe H, Tano $\mathrm{Y}$, Handa H: An SV40 immortalized human corneal epithelial cell line and its characteriaztion. Invest Ophthalmol Vis Sci I995, 36:6|4-62|

10. Reina J, Fernandez-Baca V, Blanco I, Munar M: Comparison of Madin-Darby canine kidney cells (MDCK) with a green monkey continuous cell line (Vero) and human embryonated cells (MRC-5) in the isolation of Influenza A virus from nasopharyngeal aspirates by shell vial culture. J Clin Microbiol 1999, 35:1900-190|
II. Walpita $\mathrm{P}$, Darougar $\mathrm{S}$, Thaker $\mathrm{U}$ : A rapid and sensitive culture test for detecting herpes simplex virus from the eye. $\mathrm{Br} \mathrm{J} \mathrm{Oph}$ thalmol I 985, 69:637-639

12. Kowalski RP, Karenchak LM, Romanowski EG, Gordon YJ, the community Ophthalomologists of Pittsburg, Pennsylvania: Evaluation of the shell vial technique for the detection of ocular adenovirus. Ophthalmology 1999, 106: | 324- | 327

13. Athmanathan S, Sesha Reddy B, Rao GN: Collection of impression cytology directly on a sterile glass slide for the detection of viral antigen: An inexpensive and simple technique for the diagnosis of HSV epithelial keratitis - A pilot study. BMC Ophthalmology 200I, I:3 [http://www.biomedcentral.com/I47|-24I 5///3]

14. Johnson FB, Visick EM: A rapid culture alternative to the shell vial method for the detection of herpes simplex virus. Diag Microbiol Infect Dis 1992, 1 5:673-678

\section{Pre-publication history}

The pre-publication history for this paper can be accessed here:

http://www.biomedcentral.com/1471-2415/2/3/prepub
Publish with BioMed Central and every scientist can read your work free of charge

"BioMedcentral will be the most significant development for disseminating the results of biomedical research in our lifetime." Paul Nurse, Director-General, Imperial Cancer Research Fund

Publish with BMC and your research papers will be:

- available free of charge to the entire biomedical community

- peer reviewed and published immediately upon acceptance

- cited in PubMed and archived on PubMed Central

- yours - you keep the copyright

Submit your manuscript here: BioMedcentral.com ditorial@biomedcentral.com 